\title{
Self-administered dapsone compliance of leprosy patients in Eastern Nepal
}

\author{
Y D M VAN TRIER* $\ddagger \&$ R DE SOLDENHOFF $\dagger$ \\ * Britain Nepal Medical Trust, PO Box 9, Biratnagar, Nepal; $\uparrow N S L$ \\ Eastern Leprosy Control Project, PO Box 134, Biratnagar, Nepal
}

\begin{abstract}
Accepted for publication 27 July 1990
Summary Self-administered dapsone intake by leprosy patients in Eastern Nepal was monitored with a urine spot test. Of 341 outpatients $55(16 \cdot 1 \%)$ were found to be noncompliant. A significant relationship was found between noncompliance and age and between noncompliance and caste. Sex, disease classification, type of treatment, duration of treatment, history of leprosy reactions and travel time to the clinic did not influence the compliance.

In remote areas the urine spot test can be useful in leprosy control programmes.
\end{abstract}

\section{Introduction}

The regular intake of antimycobacterial drugs by leprosy patients is considered to be important in preventing the development of drug resistance. In the dapsone monotherapy era secondary dapsone resistance was faced; ${ }^{1}$ with the introduction and implementation of multidrug therapy (MDT) in $1982^{2}$ it is feared that resistance to rifampicin or clofazimine might develop due to irregular treatment. Since a good correlation between the intake of dapsone and clofazimine has been reported, ${ }^{3}$ dapsone compliance has been considered to be a valid indicator for compliance of patients on MDT.

In the past, several tests have been developed to measure dapsone levels in urine. The importance of a simple field test has been emphasized. ${ }^{1}$ Especially in remote areas, like large parts of Nepal, where sophisticated laboratory facilities are not available, only simple tests are feasible. A urine spot test, as described by Huikeshoven in $1986,{ }^{4}$ proved to be simple, cheap and reliable. Although in some studies this test has been found insensitive,${ }^{5}$ other studies resulted in a more favourable conclusion. ${ }^{6-8}$ Recently this test was compared with results of $\mathrm{D} / \mathrm{C}$ ratios for dapsone in urine and found to have a very high sensitivity. ${ }^{9}$

This study was done to obtain information about the compliance-rate of leprosy patients in Eastern Nepal, in the flat terai as well as in the hills, and to determine whether any patient characteristic influences this compliance rate.

† Correspondence to: Lombardkade 29 D, 3031AH Rotterdam, The Netherlands. 


\section{Patients and methods}

From April to June 1989, urine was collected from 341 leprosy outpatients on their monthly visit to the leprosy clinic, and tested immediately. A total of 278 urines $(81 \cdot 5 \%)$ were collected in the terai (lowland) at the busy Biratnagar clinic, while the other 63 urines $(18.5 \%)$ were collected in the hills at five different leprosy clinics.

Patients receiving MDT totalled $279(81 \cdot 8 \%)$ and 62 were on monotherapy $(18 \cdot 2 \%)$, because they were known to be grossly irregular clinic attenders ( 8 patients) or because of the current policy of the Biratnagar clinic (54 patients). According to this policy new patients were started on monotherapy and only changed to MDT after having attended the clinic regularly for a few months. The main justification of this policy, which is at the moment under review, is the large number of Indian patients who come across the border to the Biratnagar clinic and who have proved to be more irregular than the Nepali patients. This may pose a potential resistance problem. Patient data were collected from the files and from interviews.

The urine spot test described by Huikeshoven ${ }^{4}$ was used. Filter paper impregnated with a modified Ehrlich's reagent was prepared by the laboratory of Anandaban Leprosy Hospital. It was taken to Biratnagar and the other clinics while kept in an airtight container with silica gel and used within six weeks of preparation. Negative and positive control solutions were prepared on the spot at the different leprosy clinics; ${ }^{10}$ the negative control solution was made of $1 \mathrm{~N} \mathrm{HCl}$ and urine from a person not taking dapsone; for the positive control a dilution of crushed dapsone tablets in $1 \mathrm{~N} \mathrm{HCl}$ was added to the negative control solution.

With a drop of the positive control solution as well as with a drop of urine of a patient taking dapsone, a peripheral yellow ring (urea) and an orange central spot (dapsone) appears on the impregnated paper. A drop of $1 \mathrm{~N} \mathrm{HCl}$ was added to each spot to reduce false negative and false positive results. Tests were considered positive when the orange central spot was equal in colour or darker than the positive control. A negative test result means that dapsone was not taken according to the schedule of $100 \mathrm{mg}$ per day, and possibly that the level of dapsone in blood has fallen below the minimum inhibitory concentration for Mycobacterium leprae.

\section{Results}

The overall compliance of the patients tested was $83.9 \%$ (Table 1).

A significant relationship was found between age and noncompliance (Table 2). Patients younger than 15 years were significantly less compliant than older patients and

Table 1. Dapsone compliance.

\begin{tabular}{|c|c|c|c|}
\hline & Compliant & Noncompliant & Total \\
\hline Number & 286 & 55 & 341 \\
\hline$\%$ & 83.9 & $16 \cdot 1$ & 100 \\
\hline
\end{tabular}


Table 2. Dapsone noncompliance and patient characteristics

\begin{tabular}{|c|c|c|c|c|}
\hline & Total & Compliant & Noncompliant & $\begin{array}{c}(\%) \\
\text { Noncompliance }\end{array}$ \\
\hline \multicolumn{5}{|l|}{ Age } \\
\hline$<15$ & 27 & 18 & 9 & $33 \cdot 3$ \\
\hline $15-45$ & 219 & 181 & 38 & $17 \cdot 4$ \\
\hline$>45$ & 95 & 87 & 8 & 8.4 \\
\hline \multicolumn{5}{|l|}{ Caste } \\
\hline High & 82 & 80 & 2 & $2 \cdot 4$ \\
\hline Middle & 156 & 128 & 28 & $17 \cdot 9$ \\
\hline Low & 103 & 78 & 25 & $24 \cdot 3$ \\
\hline \multicolumn{5}{|l|}{ Region } \\
\hline Terai & 278 & 229 & 49 & $17 \cdot 6$ \\
\hline Hills & 63 & 57 & 6 & $9 \cdot 5$ \\
\hline \multicolumn{5}{|c|}{ Duration of treatment } \\
\hline$<6$ months & 107 & 89 & 18 & $16 \cdot 8$ \\
\hline$>6-24$ months & 135 & 114 & 21 & $15 \cdot 6$ \\
\hline$>24$ months & 99 & 83 & 16 & $16 \cdot 2$ \\
\hline
\end{tabular}

patients above the age of 45 were more compliant than younger patients $(P<0.025$ in Chisquare test).

Members of a higher caste were more compliant than members of middle or lower castes $(P<0 \cdot 001)$. No significant difference in compliance was found for sex, disease classification, type of treatment (MDT or mono), duration of treatment, history of leprosy reactions and time needed to travel to the clinic. In this study patients in the hills appeared to be more compliant than those in the terai, but this was not significant.

\section{Discussion}

The compliance-rate in Eastern Nepal as obtained in this study proves to be encouraging and comparable to other figures from Nepal. ${ }^{9}$ As reported from other studies ${ }^{11,12}$ there seems to be a significant relationship between noncompliance and age. This was also found in Eastern Nepal, though to our knowledge a higher compliance of patients above the age of 45 years has not been reported before. Except for the caste to which patients belonged, other significant relationships between patient characteristics and noncompliance were not found. That members of a high caste proved to be more compliant, might be explained by their usually higher socioeconomic status and level of education. A significant difference in compliance for duration of treatment as reported in other studies, ${ }^{11,13}$ was not found.

In remote areas like the hills of Eastern Nepal, the use of the urine spot test proved to be feasible. Local field staff was very motivated and enthusiastic and had no difficulties in performing the test. As the test is easy, cheap and reliable, its use in leprosy control programmes on a larger scale is strongly recommended. 


\section{Acknowledgments}

We would like to thank the laboratory staff of the Anandaban Leprosy Hospital and the Britain Nepal Medical Trust for supplying test materials; the staff of the ELCPprogramme in Biratnagar and the staff of the BNMT-clinics in the hills for their kind cooperation; Dr B Naafs for his advice.

\section{References}

${ }^{1}$ Huikeshoven H. Patient compliance with dapsone administration in leprosy. Int J Lepr, 1981; 49: $228-58$. Thesis.

2 WHO Study Group. Chemotherapy of leprosy for control programmes. WHO Technical Report series, 1982; No. 675, Geneva.

3 Ellard GA, Pannikar VK, Jesudasan K, Christian M. Clofazimine and dapsone compliance in leprosy. Lepr Rev, 1988; 59: 205-13.

${ }^{4}$ Huikeshoven H. A simple urine spot test for monitoring dapsone self-administration in leprosy treatment. Bulletin of WHO, 64: 1986; 21: 279-81.

5 Ellard GA, Gammon PT, Helmy HS, Rees RJW. Urine tests to monitor the self-administration of dapsone by leprosy patients. Am J Trop Med Hyg, 1974; 23: 464-70.

${ }^{6}$ Huikeshoven H, Madarang MG. Spot test for detection of dapsone in urine: an assessment of its validity and interpretation in monitoring dapsone self-administration. Int $J$ Lepr, 1986; 54: 21-4.

7 Irudaya Raj PP, Lourdumary S, Asschof M, Balakrishnan S. A comparison of screening tests for dapsone in urine. Lepr India, 1983; 55: 528-38.

8 Kumar A, Balakrishnan S. Operational study to monitor the regularity of dapsone intake by leprosy outpatients. Lepr India, 1983; 55: 521-7.

9 Roche PW, Failbus S, Britton W. Self administered drug compliance in Nepali leprosy patients. Trop Doctor, 1989; 19: 59-61.

${ }^{10}$ Huikeshoven $\mathrm{H}$. A spot test for dapsone in urine. Technical guide for testing patient compliance with dapsone intake in leprosy. Royal Tropical Institute, Amsterdam; copies available through ILEP.

11 Kumar A, Balakrishnan S. Monitoring the regularity of self-administration of dapsone by leprosy patients. Lepr India, 1982; 54: 664-70.

12 Kumar A. Treatment compliance by leprosy outpatients and its monitoring under field conditions. Lepr India, 1984; 56: 313-18.

13 Asbeck-Raat A-M v, Becx-Bleumink M. Monitoring dapsone self-administration in a multidrug therapy programme. Lepr Rev, 1986; 57: 121-7.

\section{La complaisance des patients de lèpre qui se sont auto-administrés de dapsone}

\section{Y D M VAN TRIER ET R DE SOLDENHOFF}

Sommaire - La prise de dapsone auto-administrée par des patients au Népal Oriental a été surveillée par moyen d'un essai superficiel d'urine. Les résultats ont montré que de 341 patients, 56 (16,1\%) n'ont pas suivi le traitement. Une corrélation importante a été observée entre cette non-conformité et l'âge et entre la non-conformité et la caste. Le sexe, la classification de la maladie, le type de traitement, la durée du traitement, le passé médical de réactions de lèpre et le temps de voyage à la clinique n'ont pas influencé la conformité.

Dans des zones écartées, l'essai superficiel d'urine peut être utile dans les programmes de contrôle de la lèpre. 


\section{La conformidad de autoadministración de dapsona en pacientes de lepra en el Nepal Oriental}

\section{VAN TRIER Y DE SOLDENHOFF}

Resumen - Se investigó la toma de dapsona autoadministrada por pacientes de lepra en el Nepal Oriental por medio de una prueba superficial de orina. Según los resultados, de 34l pacientes externos, 55 (el 16,1\%) no habían seguido el tratamiento. Se observó una correlación importante entre esta no conformidad y la edad y la no conformidad y la casta de los pacientes. El sexo, la clasificación de la enfermedad, el tipo de tratamiento, la duración del tratamiento, los antecedentes de reacciones de lepra y la duración del viaje hasta la clínica no afectaron la conformidad.

En zonas remotas la prueba superficial de orina puede ser útil en los programas de control de la lepra. 